Acad. Marjan BLAŽIČ, Ph.D.

УДК 37.02

Novo mesto, Slovenia

Dragana STANOJEVIĆ, Ph.D.

37.042:159.928.23

-оригинални научни рад-

Teacher Training Faculty in Vranje, Serbia

\title{
TEACHERS' UNDERSTANDING OF GIFTEDNESS
}

\begin{abstract}
Today, no educational institution can escape the problem of working with gifted pupils. Gifted pupils are classified into the group of children with special needs, which means that they should be recognised as such and enabled to develop their abilities with appropriate didactic approaches. In the first part, the authors of this paper warn about unclear definitions of the terms intelligence, giftedness and talent, due to which it is even more difficult to identify them. All the definitions have in common the finding that the high achievement of gifted pupils is an important differentiating factor and that gifted pupils have specific traits in cognitive thinking, learning performance, motivation and the social-emotional area. Different authors offer different methodologies for identifying gifted pupils, which emphasise the teacher's observation of the child, school achievements and intelligence tests. The authors found that a three-phase model for detecting gifted pupils (recording, identification and the notifying and opinion of parents) has been established in Europe. In the empirical part, the authors examined the ability to recognise those traits of gifted pupils that determine the phenomenon of giftedness. Results show that teachers recognise and identify these traits, but not reliably enough. Possible interpretations are inadequate education of teachers in the area of giftedness, which is consequently shown in inappropriate didactic approaches in working with gifted pupils.
\end{abstract}

Keywords: gifted pupils, specific traits, identification, didactic approaches.

\section{Introduction}

At school, teachers often work with gifted pupils, but they rarely plan special activities besides additional and more complex tasks. In the first triad, the work is performed in the same manner as with other pupils, in the forms of internally differentiated instruction. Care for the gifted is part of the school programme, an important part of its plan and vision, but unfortunately, the vision is understood differently by teachers.

Gifted children are classified in the group of children with special needs because they have different abilities and the needs arising from those abilities. In addition to standard curricula, gifted and talented pupils need adjusted instruction and activities in order to develop their abilities. Partial studies on didactic approaches to the education of gifted children show that 
teachers are insufficiently familiar with their characteristics and how to work with them, despite the fact that the National Curriculum Council discussed and adopted a document on the concept of working with gifted pupils in 1998.

Gifted, talented, creative and genius children have always aroused admiration and awe in people, as well as fear and envy. In the past two decades, special attention has been paid to them, since the Primary School Act defines gifted children as children with special needs because their needs are different from the needs of their peers. Well-organised, diverse, interesting and challenging instruction adjusted to pupils as well as other activities allow the pupils to develop their full potential.

Working with gifted pupils is a demanding and responsible job which requires extensive knowledge and great efforts from the teacher. The role of the teacher is to identify gifted pupils and appropriately guide them to develop their areas of giftedness, and perhaps even discover a new gift. They should have as many opportunities as possible - not only to develop their areas of giftedness, but also to ensure a proper, comprehensive development of all the areas, especially their personality and social relationships, which are often neglected. The teacher should help gifted pupils realise why they see themselves in that way as well as help them understand their relationships with others and develop their identity. The gifted should recognise their abilities and limitations. They have to develop their responsibility and independence in the development of their giftedness (Maehler, Hofmann, 2008).

Gifted children are children with special needs because their needs are different from the needs of their peers. For that reason, care for gifted children should be provided on all the levels - it should connect the whole living space of the pupil, meaning family, school and environment. Well-organised instruction allows an individual to develop in accordance with his/her potential. In that case, the role of the teacher is to identify such pupils, guide them and show them the ways of learning. Thus, they can find out how to get information, how to solve problems, test assumptions, what the advantages of cooperation are, how to resolve conflicts and how to manage oneself and others. It is essential to ensure empirical learning to pupils, since they learn the most from their experience. Encouraging their development directs them to responsible planning of their progress and the autonomy of personality.

Von Kraft (2008) stated that giftedness should be encouraged in such a way that it becomes the best activity in free time, since giftedness can only develop when the child has the opportunity to show it. Therefore, the most important thing is to prevent that encouraging giftedness becomes a lesson that reminds of real school. Unfortunately, pupils spend a great deal of time in organised learning, which is why general and specific didactic approaches need to be constantly developed and adjusted to individual possibilities of the learning situation and the needs of concrete pupils. 
There is no uniform definition of giftedness in professional literature because gifted children are not a homogeneous group. Their giftedness is shown in different forms and scopes. Today, there are mostly multidimensional models of giftedness. Previous unidimensional models are in decline, but there are still various views on giftedness (Bezić et al., 2006; Blažič, 2003a).

Older definitions reduce giftedness to intelligence. These definitions do not correspond to subsequent findings about the prognostic validity of intelligence tests for creativity. One of the most commonly used definitions in the world is the definition stated in the Gifted and Talented Children's Education Act passed in the USA in 1978. According to this definition, gifted and talented children are those children and adolescents who show high achievement or potential in areas such as intellectual, creative, specific academic, leadership or visual and performing talent at the preschool, primary or secondary school level, and who need specifically adjusted programmes and activities, in addition to their regular school programme (Travers, Elliot and Kratochwill, 1993, p. 447). This definition emphasises that gifted and talented children include those with actual high achievement and those with potential abilities for such achievement in the following areas: general intellectual ability, specific academic aptitudes, creative and productive thinking, leadership ability or the visual and performing arts.

In the definition, psychomotor abilities are not specifically emphasised because psychomotor talent is of artistic nature, such as dance, and is included in performing arts abilities, whereas schools (in the USA) provide appropriate care for children talented in sport. Moreover, the definition includes high general intellectual ability as well as talents in specific academic areas, arts, creativity and leadership. This means that giftedness can be general or specific. In the definition, giftedness is used for high general ability that allows the achievement of extreme results in several areas at the same time, whereas talent is used for high specific abilities that lead to success in special areas. Such terminological differentiation of both types of giftedness is reasonable and should therefore be used more consistently in communication about gifted children. Finally, the aforementioned definition also stresses that gifted and talented pupils need adjusted instruction and activities in order to develop their abilities, in addition to standard curricula.

Therefore, the traditional criterion of giftedness is high general intelligence which is defined by an intelligence quotient of 130 or above. However, this definition often does not consider very creative children (whose unusual replies often lower results in intelligence tests), children of minorities (whose abilities are likely to be less developed) and children with specific abilities (who may just average or even have problems with learning in other areas). A broader definition therefore includes children who show high potential or achievement in one or several of the following areas: general intelligence, specific ability (e.g. mathematics, natural sciences, etc.), creative 
and productive thinking, leadership, artistic talent (painting, writing, music, acting) or psychomotor skills (Papalia, 2003). Nevertheless, I believe that IQ remains an important and sometimes a deciding factor.

Scientists who examine gifted pupils mostly agree that these pupils surpass a comparative group of same age children. There are differences when they try to define criteria for giftedness in connection with the following questions:

- in what way gifted pupils surpass their peers or in what they are better than them (either in general intelligence, creativity, school grades, moral judgement or perhaps in several things at the same time);

- how giftedness should be determined (either by standardised ability tests, on the basis of teacher nominations, previous achievements at school or perhaps in another way);

- to what extent children should surpass others to be defined as gifted (by being 50,80, 90 or even $99 \%$ better than their peers);

- who a comparative group should include (Bezić et. al., 2006).

Gifted pupils have certain personality traits that other pupils do not have, or they are more expressed. However, these pupils are not a homogeneous group. There are differences within a group of gifted pupils. Personality traits found in a group of gifted children refer to various areas: cognitive thinking (divergent, logical thinking, vivid imagination, careful observation, good memory, humour) learning performance (knowledgeability, learning achievement, rich vocabulary, reading), motivation (high goals, persistence, curiosity) social and emotional (nonconformity, a sense of fairness, independence, empathy). More consistently individual traits are expressed in pupils, more likely it is that they are gifted.

Detecting gifted pupils is a professionally demanding job and, therefore, no uniform methodology of detecting exists in the world. Authors often quote Marland (Heller, 2000), who offers the prevailing identification methods in his works. According to his opinion, the most important thing is the teacher's observation of the pupil, followed by school achievement, intelligence tests, and creative tests, which he finds somewhat less important. In any case, it can be established that detecting gifted pupils means observing their and identifying or recognising the signs of giftedness.

Given the aforementioned methodological inconsistency, there is a three-phase model for detecting gifted pupils: recording, identification as well as the notifying and opinion of parents.

A record of pupils who could be gifted is kept in the first trimester of primary school, usually at the end of Grade 3 . The record is made based on various criteria, such as academic achievement, students' achievement, the teacher's opinion about them, their participation and results in regional and state competitions, permanent activities in which they achieve above average results and the opinion of the school counselling service. 
The phase of identification takes place in the beginning of the second triad, and includes a detailed treatment of the recorded pupils, taking into consideration the following criteria (Bezić et al., 2006):

- teachers' grades using a grading instrument;

- the result of an ability test and

- the result of a creativity test.

The decision on the giftedness of a pupil is made at the teaching staff meeting which is participated by the school counselling service.

The notifying and opinion of parents is the last phase in the process of detecting gifted children. The parents of a gifted child are notified by the counselling service together with the class teacher of the finding that their child is gifted, and asked for their opinion about the child's giftedness. The parents are familiarised with the activities of detecting gifted pupils and plans for the further development of the child. In cooperation with the gifted pupil and his/her parents, teachers design an individualised programme.

High grades at school are definitely one of the factors, but not necessarily a condition to discuss giftedness. As signs of giftedness, other variables should be taken into account, e.g. extra-curricular activities and various hobbies (Feger, 2005).

Work with gifted pupils should be started as soon as possible. In the first triad, the work is performed in the form of differentiated instruction, in the form of internal and flexible differentiation in the second triad, and in the form of partial external differentiation in the third triad. In addition to early detection of gifted pupils and the organisation of various forms of differentiated work, they need to be continuously monitored. This involves the monitoring of the whole development of the gifted, of all the areas of personality. Effective care for gifted pupils means appropriate material and personnel conditions as well as continuous professional training in the field of detecting and working with them. Care for gifted pupils is part of the school programme, an important part of the school's plan and vision, which is an important task of the management.

Quality instruction presents the basic and irreplaceable factor of the optimal development of a gifted child. The instruction which activates pupils, where individual special characteristics are taken into consideration, and which provides numerous opportunities to pupils for creative work where positive social relationships prevail. Top-quality instruction cannot be replaced by other systems of individual measures for stimulating the development of gifted pupils. The instruction which meets the basic professional and pedagogical requirements offers a favourable atmosphere in which every step of progress is acknowledged and where the process of learning is connected with the life experiences of pupils. Such instruction also has an effect on the inclusion of pupils in leisure activities. Pupils are stimulated to extensively deal with problems that they previously discussed during class. 
Here is a list of some didactic measures which have extremely positive effects on the development of gifted pupils:

- problem situations (tasks) should be adjusted to individual characteristics of pupils;

- tasks (questions) should be exclusively productive rather than reproductive by nature; they should therefore be more complex and include higher taxonomic levels (setting high requirements);

- stimulating the production of original ideas, which are positively evaluated; pupils should present these ideas to other pupils;

- in the classroom (instruction), pupils should be stimulated to seek different, non-typical solutions (stimulating convergent mental pathways);

- directing pupils to various extra-curricular institutions that organise enrichment programmes and preparations for various competitions for gifted and talented pupils (Maehler, Hofmann, 2008).

Based on the empirical data gathered in the scope of our research, we found that the most important means for stimulating the development of gifted pupils are leisure activities at school, followed by the educational activities for stimulating the development of the gifted which are organised by different institutions unrelated to school (clubs, societies) with highly qualified staff, whereas instruction is mentioned in the last place, often being reproductive in primary schools, and as a rule, in secondary schools. The data is comparable to the data stated by American scientists, e.g. R. Wolf from the University of Chicago (Blažič, 2003, p. 18).

The specific features of extra-curricular stimulation of the development of gifted pupils can be defined in comparison with instruction, as follows:

- the motivational basis of pupils changes due to the voluntary character of activities in free time, where hobbies are emphasised;

- pupils are more intensively engaged in the realisation of tasks that they formed themselves;

- the complexity of programmes poses a challenge to gifted pupils, which is different compared to standard, very limited partial tasks during class;

- compared to instruction, there is a significant difference in the ratio between the decisions of the pupil and others due to the absence of the syllabus; outside school;

- there is an increase in productive and creative activities for pupils

- we can establish that there are more intense social relationships (leader-pupil, pupil-pupil, staff-pupil) and a higher level of cooperation and communication;

- enrichment programmes enable the cooperation of external specialists in stimualting the development of gifted children. 


\section{Methodology}

Research Aims. The empirical research was conducted with the aim of examining whether teachers at the lower and upper primary level are familiar with the theory of giftedness and how often they are able to recognise the characteristics in learning performance, as well as cognitive, motivational and social-emotional areas which define a gifted pupil, and based on that, appropriately articulate adequate didactic actions.

Sample Description. The survey questionnaire was completed by 136 primary school teachers, of which $68(50 \%)$ taught at the lower level and 68 taught at the upper level. The structure of respondents with regard to their years of service was as follows: the share of beginners (up to 5 years of service) was $14.7 \%$, whereas $42.6 \%$ were teachers with $6-20$ years of service, and the same share of the respondents had more than 20 years of service. Just over a half of respondents $(54.4 \%)$ completed vocational college, whereas the remaining respondents have university-level education.

Methods, Procedures and Instruments. We used a descriptive, nonexperimental method of empirical pedagogical research. Data was collected using a questionnaire, which included open- and closed-type questions. The questionnaire has standard characteristics of measuring: validity (review of experts), reliability (Cronbach's alfa is 0.73 ), and objectivity was ensured by clear instructions for completing the questionnaire.

Data Processing. The collected data were processed at the level of descriptive and inferential statistics. The data was processed using the SPSS programme, based on which results were interpreted.

\section{Results and Interpretation}

Based on the finding that gifted pupils have certain personality traits that are not seen in other pupils, or they are more expressed in gifted pupils, we familiarised lower and upper primary level teachers with some traits that define cognitive thinking, learning performance, motivation and the socialemotional area, and asked them to determine the importance of each trait in defining giftedness. They could add subjectively identified traits to every area. 


\section{Cognitive thinking}

Table 1: Identified traits of gifted pupils in the area of cognitive thinking.

\begin{tabular}{|c|c|c|c|c|}
\hline Identified traits & $\begin{array}{l}\text { Lower } \\
\text { primary } \\
\text { level }\end{array}$ & $\begin{array}{l}\text { Upper pri- } \\
\text { mary level }\end{array}$ & Total & $\chi^{2}$ \\
\hline $\begin{array}{l}\text { Developed logical thinking } \\
\text { (achieving high taxonomic le- } \\
\text { vels) }\end{array}$ & $\begin{array}{c}56 \\
41.2 \%\end{array}$ & $\begin{array}{c}50 \\
36.8 \%\end{array}$ & $\begin{array}{c}106 \\
77.9 \%\end{array}$ & $\chi^{2}>\chi_{0.05}^{2}$ \\
\hline $\begin{array}{l}\text { Developed divergent thinking } \\
\text { (creativity, innovation) }\end{array}$ & $\begin{array}{c}52 \\
38.2 \% \\
\end{array}$ & $\begin{array}{c}36 \\
26.5 \%\end{array}$ & $\begin{array}{c}88 \\
64.7 \% \\
\end{array}$ & $\chi^{2}>\chi_{0.05}^{2}$ \\
\hline Good memory & $\begin{array}{c}25 \\
18.4 \%\end{array}$ & $\begin{array}{c}26 \\
19.1 \%\end{array}$ & $\begin{array}{c}51 \\
37.5 \% \\
\end{array}$ & $\chi^{2}>\chi_{0.05}^{2}$ \\
\hline Accurate observations & $\begin{array}{c}8 \\
5.9 \% \\
\end{array}$ & $\begin{array}{c}21 \\
15.4 \% \\
\end{array}$ & $\begin{array}{c}29 \\
21.3 \% \\
\end{array}$ & $\chi^{2}>\chi_{0.05}^{2}$ \\
\hline Vivid imagination, creativity & $\begin{array}{c}13 \\
9.6 \% \\
\end{array}$ & $\begin{array}{c}14 \\
10.3 \% \\
\end{array}$ & $\begin{array}{c}27 \\
19.9 \% \\
\end{array}$ & $\chi^{2}>\chi_{0.05}^{2}$ \\
\hline Sense of humour & $\begin{array}{c}11 \\
8.0 \%\end{array}$ & $\begin{array}{c}2 \\
1.5 \%\end{array}$ & $\begin{array}{c}13 \\
9.5 \%\end{array}$ & $\chi^{2}>\chi_{0.05}^{2}$ \\
\hline
\end{tabular}

In the area of cognitive thinking, teachers appropriately recognised the characteristics of gifted pupils. The majority (77.9\%) believe that logical thinking is one of the main determinants which are typical of gifted pupils, since it involves analysing, summarising, generalising and making conclusions in the scope of various cognitive taxonomies, and in addition to that, the pupils should include these traits in their everyday work of solving different problems. Almost two thirds of respondents $(64.7 \%)$ believe that divergent thinking, whose main characteristic is creativity, is important, whereas good memory is reported by $37.5 \%$ of respondents, a fifth mentioned vivid imagination and accurate observations, and just under a tenth (9.5\%) also mentioned a sense of humour.

With regard to the level of teaching, teachers at the lower primary level largely recognised divergent thinking, which is shown by original and innovative approaches, developed logical thinking, which is shown by achieving high taxonomic levels in the cognitive area, whereas a smaller percentage found a sense of humour significant. For upper primary level teachers, good indicators of giftedness are vivid imagination, accurate observations and good memory, but there is no significant statistical difference in their opinions compared to lower primary level teachers. 


\section{Learning performance}

Table 2: Identified traits of gifted pupils in the area of learning performance

\begin{tabular}{|c|c|c|c|c|}
\hline Identified traits & $\begin{array}{l}\text { Lower pri- } \\
\text { mary level }\end{array}$ & $\begin{array}{l}\text { Upper prima- } \\
\text { ry level }\end{array}$ & Total & $\chi^{2}$ \\
\hline High learning achievement & $\begin{array}{c}58 \\
42.6 \%\end{array}$ & $\begin{array}{c}61 \\
44.9 \% \\
\end{array}$ & $\begin{array}{c}119 \\
87.5 \%\end{array}$ & $\chi^{2}>\chi_{0.05}^{2}$ \\
\hline Speed of work & $\begin{array}{c}30 \\
22.1 \% \\
\end{array}$ & $\begin{array}{c}37 \\
27.2 \% \\
\end{array}$ & $\begin{array}{c}67 \\
50.2 \% \\
\end{array}$ & $\chi^{2}>\chi_{0.05}^{2}$ \\
\hline Curiosity & $\begin{array}{c}48 \\
35.3 \% \\
\end{array}$ & $\begin{array}{c}11 \\
8.1 \%\end{array}$ & $\begin{array}{c}59 \\
43.4 \% \\
\end{array}$ & $\chi^{2}>\chi_{0.05}^{2}$ \\
\hline Knowledgeability & $\begin{array}{c}20 \\
14.7 \%\end{array}$ & $\begin{array}{c}22 \\
16.2 \%\end{array}$ & $\begin{array}{c}42 \\
30.9 \% \\
\end{array}$ & $\chi^{2}>\chi_{0.05}^{2}$ \\
\hline Rich vocabulary & $\begin{array}{c}25 \\
18.4 \% \\
\end{array}$ & $\begin{array}{c}12 \\
8.8 \% \\
\end{array}$ & $\begin{array}{c}37 \\
27.2 \% \\
\end{array}$ & $\chi^{2}>\chi_{0.05}^{2}$ \\
\hline Artistic skills & $\begin{array}{c}2 \\
1.5 \%\end{array}$ & $\begin{array}{c}5 \\
3.7 \%\end{array}$ & $\begin{array}{c}7 \\
5.2 \%\end{array}$ & $\chi^{2}>\chi_{0.05}^{2}$ \\
\hline
\end{tabular}

Teachers at the lower and upper primary level put learning achievements in the first place. The speed of work is places second, which means that they find responses to the teacher's questions an important determinant. This trait is somewhat more identified by teachers at the upper primary level rather than teachers at the lower primary level. Pupils' curiosity is placed third, as the second most important traits for lower primary level teachers, which triggers numerous questions by pupils that often require professionally demanding answers by teachers. Data shows that teachers at the upper primary level do not recognise the factor of greater activity during the learning process. Compared to teachers at the lower primary level, the upper primary level teachers also mostly recognise the importance of rich vocabulary as a factor of progress, success and a determinant of giftedness. Respondents barely recognise the knowledgeability of pupils, and they also believe that artistic skills in the area of music, drawing and sport are not included in the description of giftedness. 


\section{Motivation}

Table 3: Identified traits of gifted pupils in the area of motivation

$\left.\begin{array}{|c|c|c|c|c|}\hline \text { Identified traits } & \begin{array}{c}\text { Lower prima- } \\ \text { ry level }\end{array} & \begin{array}{c}\text { Upper prima- } \\ \text { rylevel }\end{array} & \text { Total } & \chi^{2} \\ \hline \multirow{2}{*}{\text { Striving for excellence }} & 29 & 26 & 55 & \chi^{2}>\chi_{0.05}^{2} \\ \hline \multirow{2}{*}{\text { Curiosity }} & 21.3 \% & 19.1 \% & 40.4 \%\end{array}\right)$

Respondents (40.4\%) believe that a desire to achieve excellence is a dominant trait which defines motivation, followed by curiosity $(38.9 \%)$, high energetic potential and persistence. They hardly recognise the performance attitude of pupils. With regard to the level of teaching, we can establish that for most traits there are no significant statistical differences in the replies of lower and upper primary teachers, which means that they identified the same traits in approximately the same scope, except the difference in recognising curiosity, which was largely identified by teachers at the lower primary level.

\section{Social-emotional area}

Table 4: Identified traits of gifted pupils in the social-emotional area

\begin{tabular}{|c|c|c|c|c|}
\hline Identified traits & $\begin{array}{l}\text { Lower prima- } \\
\text { ry level }\end{array}$ & $\begin{array}{c}\text { Upper primary } \\
\text { level }\end{array}$ & Total & $\chi^{2}$ \\
\hline Nonconformity & $\begin{array}{c}52 \\
38.2 \% \\
\end{array}$ & $\begin{array}{c}61 \\
44.9 \% \\
\end{array}$ & $\begin{array}{c}113 \\
83.1 \% \\
\end{array}$ & $\chi^{2}>\chi_{0.05}^{2}$ \\
\hline Independence & $\begin{array}{c}36 \\
26.5 \%\end{array}$ & $\begin{array}{c}38 \\
27.9 \%\end{array}$ & $\begin{array}{c}74 \\
54.4 \% \\
\end{array}$ & $\chi^{2}>\chi_{0.05}^{2}$ \\
\hline Sense of fairness & $\begin{array}{c}22 \\
16.2 \% \\
\end{array}$ & $\begin{array}{c}19 \\
14.0 \% \\
\end{array}$ & $\begin{array}{c}41 \\
30.2 \% \\
\end{array}$ & $\chi^{2}>\chi_{0.05}^{2}$ \\
\hline Empathy & $\begin{array}{c}26 \\
19.1 \%\end{array}$ & $\begin{array}{c}13 \\
9.6 \%\end{array}$ & $\begin{array}{c}39 \\
28.7 \%\end{array}$ & $\chi^{2}>\chi_{0.05}^{2}$ \\
\hline Capable leader & $\begin{array}{c}28 \\
20.6 \% \\
\end{array}$ & $\begin{array}{c}6 \\
4.4 \% \\
\end{array}$ & $\begin{array}{c}34 \\
25.0 \% \\
\end{array}$ & $\chi^{2}>\chi_{0.05}^{2}$ \\
\hline Good organiser & $\begin{array}{c}5 \\
3.7 \%\end{array}$ & $\begin{array}{c}21 \\
15.4 \%\end{array}$ & $\begin{array}{c}26 \\
19.1 \% \\
\end{array}$ & $\chi^{2}>\chi_{0.05}^{2}$ \\
\hline
\end{tabular}


Gifted pupils are seen as nonconformists by $83.1 \%$ of respondents. To teachers, this term signifies pupils who have difficulties in adjusting and accepting the general opinion, and who are often loners, find it difficult to participate in group work, are often asocial and immature as well as have problems with discipline. Most teachers defined this trait as a negative characteristic. More than half (54.4\%) of respondents believe that gifted pupils are quite independent in learning. They also identified a clearly expressed sense of fairness in these pupils, and the ability to show empathy. A cause for concern is that the majority of teachers recognise a gifted pupil as a person who has deficits in the social-emotional area.

There is a statistically important difference in the replies of teachers at the lower and upper primary level $\left(\chi^{2}>\chi_{0.05}^{2}\right)$ for two items. Lower primary level teachers believe that a gifted pupil is a good leader, whereas upper primary level teachers recognised their sense of organisation. We assume that the difference in their replies arises from the development level of the child at the lower or upper primary school. At the lower primary level, the organiser is mostly the teacher, since children are not yet able to play that role, whereas the upper primary level requires a number of organisational skills of pupils in the scope of various pedagogical and didactic measures.

The questionnaire partly also refers to the internal organisation of instruction. We prepared five statements. The replies gave us an insight into their opinions about gifted pupils.

Table 5: Some opinions of teachers about gifted pupils

\begin{tabular}{|c|c|c|c|c|c|c|}
\hline \multirow{3}{*}{ Statement } & \multicolumn{6}{|c|}{ Answers } \\
\hline & \multicolumn{3}{|c|}{ Yes } & \multicolumn{3}{|c|}{ No } \\
\hline & $L P$ & $U P$ & Total & $L P$ & $U P$ & Total \\
\hline $\begin{array}{l}\text { Gifted children importantly } \\
\text { contribute to the classroom } \\
\text { climate. }\end{array}$ & $\begin{array}{c}56 \\
82.4 \%\end{array}$ & $\begin{array}{c}46 \\
67.6 \%\end{array}$ & $\begin{array}{c}102 \\
75.0 \%\end{array}$ & $\begin{array}{c}12 \\
17.6 \%\end{array}$ & $\begin{array}{c}22 \\
32.4 \%\end{array}$ & $\begin{array}{c}34 \\
25.0 \%\end{array}$ \\
\hline $\begin{array}{l}\text { There are more gifted boys than } \\
\text { girls. }\end{array}$ & $\begin{array}{c}12 \\
20.7 \%\end{array}$ & $\begin{array}{c}8 \\
10.3 \%\end{array}$ & $\begin{array}{c}20 \\
14.7 \%\end{array}$ & $\begin{array}{c}46 \\
79.3 \%\end{array}$ & $\begin{array}{c}70 \\
89.7 \%\end{array}$ & $\begin{array}{c}112 \\
85.3 \%\end{array}$ \\
\hline $\begin{array}{l}\text { Fast progress is the most im- } \\
\text { portant for the development of } \\
\text { gifted pupils. }\end{array}$ & $\begin{array}{c}26 \\
38.2 \%\end{array}$ & $\begin{array}{c}18 \\
26.5 \%\end{array}$ & $\begin{array}{c}44 \\
32.4 \%\end{array}$ & $\begin{array}{c}42 \\
61.8 \%\end{array}$ & $\begin{array}{c}50 \\
73.5 \%\end{array}$ & $\begin{array}{c}92 \\
67.6 \%\end{array}$ \\
\hline $\begin{array}{l}\text { There are identical criteria for } \\
\text { assessing gifted pupils. }\end{array}$ & $\begin{array}{c}52 \\
76.5 \%\end{array}$ & $\begin{array}{c}44 \\
64.7 \%\end{array}$ & $\begin{array}{c}96 \\
70.8 \%\end{array}$ & $\begin{array}{c}16 \\
23.5 \%\end{array}$ & $\begin{array}{c}24 \\
35.3 \%\end{array}$ & $\begin{array}{c}40 \\
29.4 \%\end{array}$ \\
\hline $\begin{array}{l}\text { Gifted pupils can successfully } \\
\text { develop abilities in their de- } \\
\text { partment. }\end{array}$ & $\begin{array}{c}50 \\
73.5 \%\end{array}$ & $\begin{array}{c}36 \\
52.9 \%\end{array}$ & $\begin{array}{c}86 \\
63.2 \%\end{array}$ & $\begin{array}{c}18 \\
26.5 \%\end{array}$ & $\begin{array}{c}32 \\
47.1 \%\end{array}$ & $\begin{array}{c}50 \\
36.8 \%\end{array}$ \\
\hline
\end{tabular}

Key: LP-lower primary level, UP-upper primary level 
Most teachers (75\%) believe that the personality traits of gifted pupils significantly contribute to the classroom climate. Given that gifted pupils generally are not conformists, we can conclude that the teacher should be prepared for their unconventional behaviour. Gifted children have to be offered appropriate activities for their cognitive and conative development.

The provocative question about the number of boys and girls as gifted pupils was replied positively by just a tenth of respondents. Data has shown that girls were not encouraged to show high achievement in recent past, but today's school and study conditions have improved this situation.

Just under a third (32.4\%) of respondents believe that fast progress is the most appropriate for the development of gifted pupils. This viewpoint is interesting, since it is generally known that accelerative measures have been gradually declining since the 1980 s due to enormous differences in the emotional and social development of gifted pupils. $67.6 \%$ of respondents believe that it is possible to ensure an appropriate development of gifted pupils by using didactic measures in their department, such as individualisation, differentiation, extra-curricular forms of education, hobbies, summer schools, etc. Most respondents also replied that assessment criteria were identical for all the pupils in the classroom.

Respondents were also asked about the greatest obstacle in working with gifted pupils. Their replies were partly expected. As the first obstacle, teachers state that they are not adequately qualified to identify and educate gifted pupils. They wish to participate in various forms of continuous education, but there is a lack of funds. The next obstacle is too great an amount of time and energy to prepare flexible, organised lessons, followed by too many pupils in the class, poor communication with the school's counselling service and too extensive syllabuses.

\section{Conclusion}

Teachers' understanding of giftedness is definitely linked with their undergraduate professional education and their experience in working with gifted pupils. The research confirmed the theoretical findings that giftedness is a sum of given and obtained traits which each individual develops in a certain proportion and which ensure above average results in one or several areas. Modern polyfactorial theories of giftedness especially emphasise dynamic processes arising from upbringing and the environment, including consequences.

Given the fact that giftedness is gradual, we are faced with a range of phenomena from a lack of giftedness to high levels of giftedness. There are qualitative and quantitative differences which teachers often do not recognise, especially because the most appreciated is universal giftedness due to relatively clear characteristics. 
The research shows that teachers at the lower and upper primary level recognise and identify the typical traits of gifted pupils, but not reliably enough. The reasons lay in the social orientation of primary school in the area of below average and problematic pupils, whereby the population of gifted pupils is neglected, as well as in inadequate education of teachers in the area of giftedness, which is consequently manifested in poor and inappropriate didactic approaches that do not include individual approaches, flexible differentiation, cooperative lessons and various enrichment programmes. The fundamental didactic studies, which require funding, would undoubtedly stimulate the development of special didactics in working with gifted pupils and therefore offer appropriate didactic solutions for the development of this population of pupils.

\section{References}

1. Bezić, T. et al. (2006). Odkrivanje nadarjenih učencev in vzgojno-izobraževalno delo z njimi. Ljubljana: Zavod RS za šolstvo.

2. Blažič, M. (2003a). Nadarjeni med teorijo in prakso: mednarodni znanstveni simpozij. Novo mesto: Slovensko združenje za nadarjene.

3. Blažič, M. (2003b). Nadarjeni - izkoriščen ali prezrt potencial. Zbornik prispevkov: mednarodni znanstveni simpozij. Novo mesto: Slovensko združenje za nadarjene.

4. Feger, B. (2005). Hochbegabung, Chancen und Probleme. Stuttgart: Verlag Hans Huber.

5. Ferbežar, I. (2008). Svetovanje nadarjenim učencem. Ljubljana: Zavod RS za šolstvo.

6. Fischer, C. (2008). Gifted Children: How to Bring Out Their Potential. Pridobljeno s spleta, dne 21.10.2013: http://www.sciam.com/article.cfm?id=coachingthe-gifted-child.

7. Heller, K.A. et al. (2000). Giftedness and Talent. Oxford: Elsevier.

8. Maehler, B., Hofmann, G. (2008). Ist mein Kind Hochbegabt? Hamburg: Rowohl Verlag.

9. Papalia, D. E. (2003). Otrokov svet. Ljubljana: Educy

10. Renzulli, J. S. (2004). Building a bridge between gifted education and total school improvement. Connecticut: The national research center on the gifted and talented.

11. Tallent-Runnels, M. K. (2007). Resources for gifted students studying the future. Gifted child today, vol 30, no. 1, pp. 50-54.

12. Travers, J.F., Elliot, S.N., Kratochwill, T.R. (1993). Effective Teaching, Effective Learning. Educational Psychology. Madison: Brown Benchmark, str. 447-464.

13. Von Kraft, T. \& Semke, E. (2008). Odkrijmo in razvijmo otrokovo nadarjenosti. Ljubljana: Mladinska knjiga.

14.Žagar, D. et al. (1999). Odkrivanje in delo z nadarjenimi učenci. Ljubljana: Strokovni svet RS za splošno izobraževanje. 


\author{
Проф. др Марјан Блажич \\ Доц. др Драгана Станојевић
}

\title{
УЧИТЕЉЕВО СХВАТАЮЕ ДАРОВИТОСТИ
}

Сажетак: Проблем рада са даровитим ученицима данас не може заобићи ниједан васпитно-образовни систем. Даровите ученике сврставамо у групу деще са посебним потребама, што значи да их треба, као такве, препознати и омогућити им развој способности одговарајућим дидактичким приступима. Аутори у првом делу рада указују на нејасне дефиничије појмова интелигенција, даровитост и таленат, што умногоме отежава њихово препознавање. Заједничко свим дефинииијама је закључак да су висока постигнућа даровитих важан фактор разликовања и да је код даровитости могуће открити специфичне способности у перформансама учења, мисаоно-сазнајном, мотивацијском и сочио-емоционалном подручју. Различити аутори дају различите методологије за идентификовање надарених ученика којима наглашавају учитељево посматрање деце, иколски успех и тестове интелигениије. Аутори наглашавају да је у Европи успостављен тростепени модел откривања даровитих ученика (евидентирање, идентификаиија, упознавање и мииљењье родитеља). У емпиријском делу, аутори су проучавали могућност идентификовања оних карактеристика даровитих ученика које детерминишу феномен даровитости. Резултати показују да учитељи препознају и идентификују ове особине, али не довољно поуздано. Разлоге је могуће наћи у недовољьој едукаиији учитеља у области даровитости, ито резултира неадекватним дидактичким приступима у раду са даровитима.

Кључне речи: даровити ученици, спещифичне особине, идентификаиија, дидактички приступи. 